\title{
Exploring the Relationship between E-Commerce Adoption and Business Strategy: An Applied Study on the Jordanian Telecommunication Companies
}

\author{
Dr. Moayyad AL-Fawaeer \\ Faculty of Finance and Business Administration \\ Department of Management, The World Islamic Sciences \& Education University \\ P.O.Box 1101, Postal Code 11947, Amman, Jordan \\ E-mail: dr.moayyad@yahoo.com
}

Received: Nov. 14, 2013

Accepted: December 15, 2013 Published: January 1, 2014

doi:10.5296/jmr.v6i1.4558

URL: http://dx.doi.org/10.5296/jmr.v6i1.4558

\begin{abstract}
This study aims to shed the light on the relation between E-commerce adoption in terms of (website for corporate, website for product / services, customer support via web contact details, online order processing online business, Web Access to order, web-based marketplaces) and business strategy (internal factors, market factors, competitive factors) at the Jordanian telecommunication companies.

The population of the study consisted of mobile communication companies operating in Jordan (Zian, Umniah, Orange), A probability sample was employed to collect the data from top and middle management team as they are working on strategic level, the sample was consisted of 100 managers and head of departments, field data was collected via questionnaire that was developed for this purpose, the study was analyzed the primary data by using several descriptive methods such as means and standard deviations and statistical methods such as multiple regression.

It was concluded from the proposed study: Jordan as a developing country is lacking the adequate infrastructure of E-commerce. The telecommunication sector in Jordan is among the potential ICT leaders that are expected to adopt high level of E-commerce locally and regionally.
\end{abstract}

Keywords: E-commerce, E-commerce adoption, Business Strategy, Jordan 


\section{Introduction}

A new era of internet and technology had a huge impact on people's lives, internet users are distributed among the globe; they are using internet at each minute and second of their lives, posting their recent activates, checking the weather, sharing their beliefs and political views, socializing with new people from different countries and cultures, expressing themselves in a way that was never available 50 years ago, also the internet usage exceeded the social activities to include conducting financial transactions during e-shopping, e-banking and e-government activities (Al-Nawayseh, 2012, Kurnia, 2008).

E-commerce adoption within the organizational context highlights the importance of being existed on the world wide network through offering information, interaction and transactions to concerned parties, the survey conducted by Ipsos (2012) in 24 countries around the world found that" A half (48\%) of citizens in 24 countries who use the internet say that: they do shop for products online, even more (61\%) use the web for the research phase, saying they 'visit sites for info on products they are thinking of buying.' Countries where online shopping has become the norm for online-connected citizens are among the world's most developed countries e.i Germany (74\%), Great Britain (74\%), Sweden (68\%), and United States (65\%)".

As reported by the Arab Advisors Group (2011) “in 2011, 24.4\% of Internet users in Jordan used e-commerce to buy products or services or pay their bills online, up from $15.4 \%$ in $2010 "$ this result indicates that the e-commerce activities are increasing among Jordanian internet users, but at the same time this percent is very low compared to the United Kingdom (UK) online shopping statistics. UK online shopping statistics show that $66 \%$ of total number users used the internet to purchase goods or services in 2011, up from $62 \%$ in 2010 , according to the Office for National Statistics.

Business strategy is the most important tool that direct the organization to achieve its goals and draw it's future grow roadmap, at the same time formulating the business strategy requires an accurate awareness about (strength, weakness, opportunities and threats) at both internal and external level, three main determinants are playing a key role in deciding the strategic objectives for any organization (Pires and Aisbett, 2003): internal factors, market factors, and competitive factors).

The provided background motivated the researcher to propose this study that aims to shed the light on the relationship of E-commerce adoption and business strategy at the Jordanian telecommunication companies.

\section{The Problem of Study}

E-commerce is new to business organizations, many scholars indicated that the gap of Ecommerce practices between developed and developing countries could be explained by considering the social cultural, political, and business environment adding to consumers' attitudes (Kurnia, 2008). Jordan as one of the developing countries lacking the adequate infrastructure and delivery services that is considered a real challenge to E-business (Al-Nawayseh, 2012); consequently the main problem of the study is the lack of theoretical and applied studies that combined between e-commerce and business strategy, So the main 
question of the study is "What is the relation between E-commerce adoption and business strategy at the Jordanian telecommunication companies?"

This question is divided into 2 sub-questions:

1. What is the level of E-commerce adoption at the Jordanian telecommunication companies?

2. What is the relation between E-commerce adoption dimensions (website for corporate, website for product / services, customer support via web contact details, online order processing online business, Web Access to order, web-based marketplaces) and business strategy at the Jordanian telecommunication companies.

\subsection{Study Objectives}

The objectives of this study are as follows:

1. Measuring the level of E-commerce adoption at the Jordanian telecommunication companies.

2. Examining the relation between E-commerce adoption and business strategy at the Jordanian telecommunication companies.

3. The study will conclude a number of findings and results that will lead researchers for future insights.

4. Provide the Jordanian telecommunication companies with recommendations in lights of the study findings.

\subsection{Study Importance}

The study importance is summarized in the following:

1) This study is considered one of the main Arabic studies that will discuss the relation between E-commerce adoption dimensions (website for corporate, website for product/services, customer support via web contact details, online order processing online business, Web Access to order, web-based marketplaces) and business strategy at the Jordanian telecommunication companies.

2) The Field of study: telecommunication companies sector is considered one of the leading sector in ICT, also it contributes significantly to the Jordanian economy.

3) This study will enhance the understanding about e-commerce adoption levels at the Jordanian telecommunication companies.

4) This study will provide future researchers with important insights that lead them to conduct more research related to the study topic.

\section{Research Model}

The model of the study contains two main variables, the independent variable is E-commerce adoption that is consists of six main damnations according to (Senarathna \& 
Wickramasuriya,2011; Kraemer et al., 2002; Yao, 2004; Govindaraju \& Chandra, 2012) website for corporate, website for product / services, customer support via web contact details, online order processing online business, web Access to order, web-based marketplaces), and the dependent variable is business strategy that will be measured using the tool of (Pires and Aisbett, 2003; Barkley et al., 2007; Tan \& Ibrahim, 2010; Yang, 2012 ) in terms of (internal factors, market factors, competitive factors).

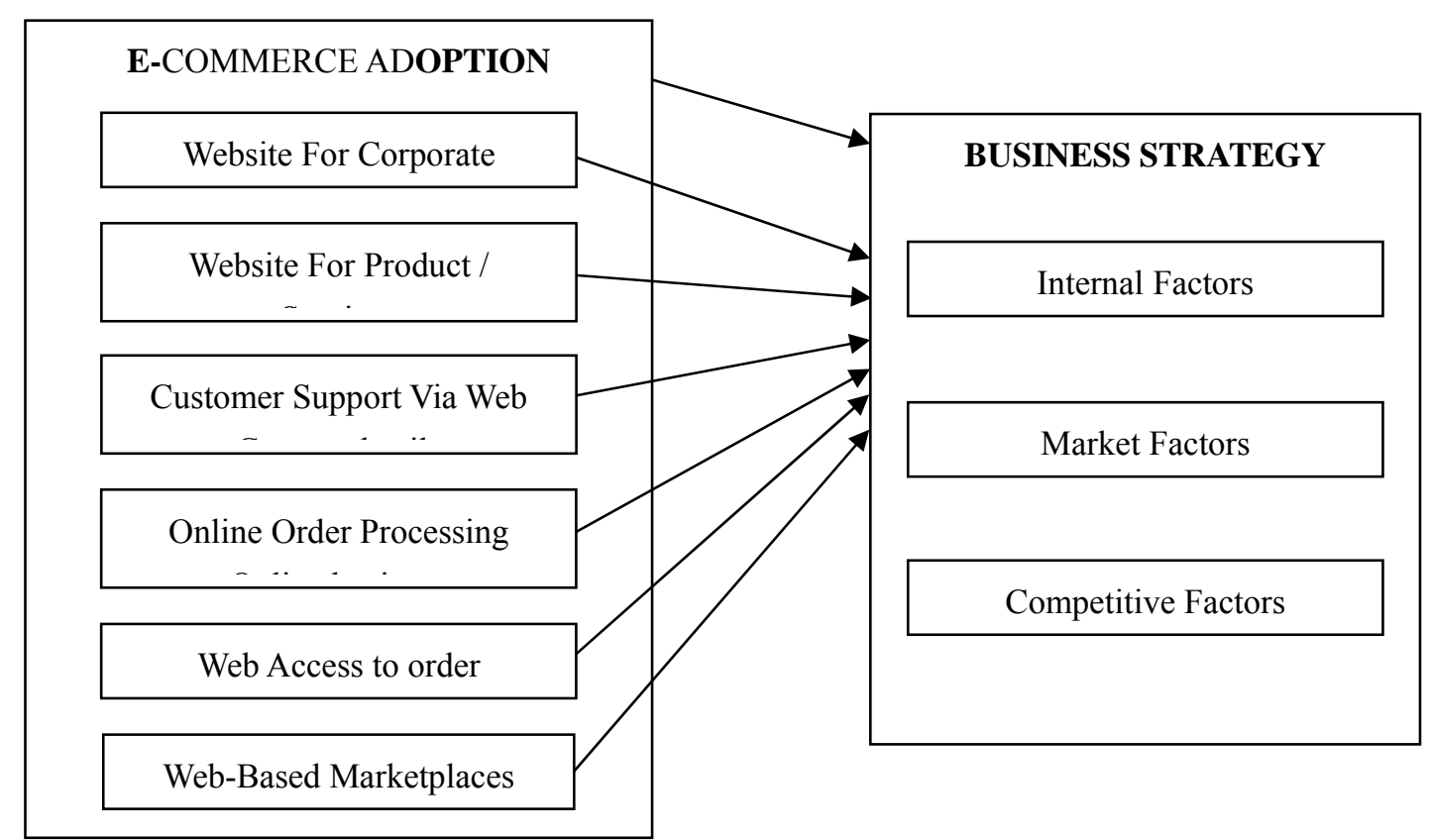

Figure 1. Study Model

\subsection{Hypotheses}

The study hypotheses were formulated based on the literature review and the previous research results as follows:

Ho1: There is no statistically significant relation between E-commerce adoption (website for corporate, website for product/services, customer support via web contact details, online order processing online business, web access to order, web-based marketplaces) and business strategy at the Jordanian telecommunication companies.

This hypothesis is divided into three sub-hypothesizes:

Ho1.1: There is no statistically significant relation between website for corporate and business strategy at the Jordanian telecommunication companies.

Ho1.2: There is no statistically significant relation between website for product / services and business strategy at the Jordanian telecommunication companies.

Ho1.3: There is no statistically significant relation between customer supports via web 
contact details and business strategy at the Jordanian telecommunication companies.

Ho1.4: There is no statistically significant relation between online order processing online business and business strategy at the Jordanian telecommunication companies.

Ho1.5: There is no statistically significant relation between web access to order and business strategy at the Jordanian telecommunication companies.

Ho1.6: There is no statistically significant relation between web-based marketplaces and business strategy at the Jordanian telecommunication companies.

\section{Procedural Definitions}

\subsection{E-commerce adoption}

it was defined to be " the average level of utilization of e-commerce solutions or applications in merchandising sourcing, logistics, general resources, management, and decision support areas" (Shen et al., 2004,3).

While e-commerce was defined as "All electronically mediated information exchanges between an organization and its external stakeholders"(Chaffey, 2011, p. 10).

\subsection{Business Strategy}

The simple definition of Business Strategy is "a long term plan of action designed to achieve a particular goal or set of goals or objectives " (Pires and Aisbett, 2003) it will be measured in terms of (internal factors, market factors, competitive factors).

\section{The Theoretical Framework}

\subsection{E-commerce Adoption}

According to Sculopa (2003) different factors play key role in e-commerce adoption such as: Organizational environment, Organizational Context, Technological Context.

Different theories tried to capture the most determinants factors of E-commerce adoption such as adopted the Technology Acceptance Model (TAM) originally coined by Davis (1989 and 1993) to reflect the e-commerce practices considering both personnel and technological influences based on the consumer. TAM includes two main positive determinants for the consumer's attitudes toward usage intention and these are: Perceived Usefulness (PU) and Perceived Ease Of Use (PEOU).

Many scholars (Senarathna \& Wickramasuriya, 2011; Kraemer et al., 2002; Yao, 2004; Govindaraju \& Chandra, 2012) indicated that there are several levels of e-commerce adoption divided on many stages as follows:

\section{Website For Corporate: \\ o Information \\ o Company Overview}




\section{1) Macrothink}

o CEO Message

o Financial facts

o What's new

o Employment opportunities

o Community involvement

2. Website For Product / Services:

o Information

o Product services (gen overview)

o Product services (specific details)

o Other services

O FAQ

o Insurance Overview

3. Customer Support Via Web Contact details:

o E-mail address

o Feedback

o Links to other sites

o Comparison with other companies

o Product services (interactive features)

4. Online Order Processing Online business

o Online accounts for buyers

5. Web Access To Order:

o Information

o Online account access

o Online access to account settings

o Online access to orders

o Order tracking functionality

6. Web-Based Marketplaces:

o An alliance with competitors

o Criteria-based product selection 
Constantinides, (2004) provided a comprehensive model summarizing the factors affecting the online consumer's behaviour based on the work of Cheung et al. (2003), it indicated that three variables impact online buyers decision process: personal and environmental (uncontrollable factors), marketing stimuli and web experience (controllable factors). These factors are explained briefly as follows:

1) Consumer Characteristics: Consumer characteristics were examined to test their impacts on: adoption of technology, trust and confidence of online shopping, purchasing intention, purchasing decisions, and repurchasing decisions.

2) Environmental Influences: Environment plays a key role in impacting consumer behaviours and perception, such as the economic and financial situation, cultural perspectives, social factors, security considerations, and political aspects.

3) Product and Services Characteristics: Price, quality and the physical characteristics such as colors, design, and packaging influence the perceived value to the consumer, also these characteristics play an important role in the evaluation processes.

4) Medium Characteristics: Providing a friendly user interface and high quality, reliable, secure, organized, high speed, and simple systems will impact the consumer behaviour positively.

5) Online Merchants and Intermediaries Characteristic: Having the right channels to acquire the needed value is playing a vital role in consumer behaviour. Online intermediaries including infomediares who provide information and discussion about the product and services that assist the customer to have clear idea about all the details, Different types of intermediaries are: "directories, search engines, malls, virtual resellers, financial intermediaries, forums, fan clubs and user groups, and evaluators (Chaffey, 2011, p. 73).

\subsection{Business Strategy}

Strategic planning process within the organizational context is directly linked to the organizational success as it was considered one of the main dimensions that directly determine the success or failure of a project.

According to Ambler (2003) the aim of the planning stage is assuring a high efficiency and effectiveness in the following factors: Quality, Cost, Schedule, Performance and Supportability.

According to (Pires and Aisbett, 2003; Barkley et al., 2007; Tan \& Ibrahim, 2010; Yang, 2012) business strategy can be measured in terms of (internal factors, market factors, competitive factors). These three components are configured into specific structures in terms of the following sub factors:

\section{1) Internal Factors:}

1. Increasing revenues

2. Decreasing Cost 


\section{Macrothink}

3. Shorter product development cycles

4. $\quad$ Reduced start up capital needs

5. Lower overheads

6. Enhancing Diversity

7. Faster transactions and cash generation

\section{2) Market Factors:}

1. Flexibility in company location

2. Accessibility to more suppliers

3. Accessibility to more buyers

4. Improving Communication

5. Info-Based produces development

\section{3) Competitive Factors:}

1. Closer customer relationships

2. Enhancing lower price competition Ability

3. Increased customer value

4. Feedback increased.

Additionally, international e-commerce has provided organizations with a platform that has helped among others: increase revenues; increase the number of customers and suppliers; provide more information about products and business partners. Similarly international e-commerce has helped these businesses access better products and services; reduce time of doing business and associated costs and improve relationships with their suppliers and customers. These benefits relate well with the main reasons why these organizations started using e-commerce in the first place which are; e- commerce is faster than traditional commerce, has information richness and would help the organization keep up with other organizations.

According to (Pires and Aisbett, 2003) table (1) indicates advantages and disadvantages of e-commerce adoption in relevant to business strategy based on their literature. 
Table 1. Advantages And Disadvantages Of E-Commerce Adoption In Relevant To Business Strategy

\begin{tabular}{|c|c|}
\hline ADVANTAGES & DISADVANTAGES \\
\hline Company location made irrelevant & Risk from unknown customers \\
\hline Reaches/creates new markets & Cultural and legal impediments \\
\hline problems solved faster & Together, large buyers have power over prices \\
\hline Increased flexibility and responsiveness & $\begin{array}{l}\text { Restricts competition: business deals only with } \\
\text { suppliers that have e-procurement systems }\end{array}$ \\
\hline Access to commercial research & Confusing and anarchic information environment \\
\hline Improved sales tracking & $\begin{array}{l}\text { Resistance to payment for services offered via the } \\
\text { web }\end{array}$ \\
\hline Faster transactions and cash generation & Loss of control through loss of relationships \\
\hline automated buying processes & Security problems \\
\hline Reduced inventories & Disrupts relationships along selling channel \\
\hline
\end{tabular}

Source: (Pires and Aisbett, 2003)

\section{Previous Studies}

The study (Waboi, 2012): the research sought to find out the effectiveness of international e-commerce as a business strategy and how it has led to business growth for motor vehicle dealers in Nairobi, Kenya. This objective was pursued by doing a survey among registered motor vehicle dealer firms selected based on their locations. It is believed that the findings of this report can be extrapolated to all motor vehicle dealers in Nairobi. Application of e-commerce must however be implemented with the challenges of using e-commerce in mind.. Data analysed showed that $95 \%$ of motor vehicle dealers in Nairobi practice international trade with a majority of them using international e-commerce in their purchasing, marketing and sales functions. International e-commerce has been widely practiced. In all these international business dealings e-commerce has played a crucial role to support the transactions. The major drawback cited that impacts on the effectiveness of international e-commerce strategy is the effect of the established business traditions and conventions.

Study of (King et al., 2004) This paper takes a game theoretic approach to study the impact of web-based e-commerce on the choice of distribution channel strategy by the retailers. The current practice by most firms is to adopt a multi-channel strategy, which includes both web-based channels and preexisting offline channels. Our analysis validates this trend by identifying it as one of the equilibriums of the game, resulting from the competitive pressure induces by the other retailers. However a more interesting outcome from our analysis is that there are other possible outcomes. The other possible outcomes include one where some sellers adopt a coordinated dual channel)i.e., both online and offline) strategy while the others continue selling through traditional offline channels, and another one where all the sellers 
switch to online channels. The latter outcome is unlikely to occur for industries where traditionally offline sellers have invested heavily in distribution-specific assets. However, it does provide an explanation for new web-based sellers' reluctance to include offline channels in their overall channel strategy.

The study of (Fruhling and Digman, 2000) This paper examines the impact of electronic commerce on business-level strategies. The paper examines electronic commerce (E.C) from the perspective of intra-business E.C., business-to-business E.C., business-toconsumer E.C., and value/supply chain management. Business-level strategies are considered to include: added value, differentiation, cost leadership, focus, and growth source. The paper concludes that E-commerce will have significant impacts on each of the business-level strategic areas.

The study of (aragozoglu and Lindell, 2004) explores the electronic commerce (e-commerce) involvement of small and medium-sized enterprises (SMEs) in terms of the strategic, operational, and performance aspects. Findings are reported from a survey of SMEs in northern California. The results show that SMEs tend to pursue e-commerce strategies associated with customer base expansion and customer service consistent with their bricks-and-mortar competitive strategies and build e-commerce operations consistent with their e-commerce strategies. These e-commerce strategies also contribute to the SMEs' sales growth and profitability. However, e-commerce strategy associated with purchasing management is the least favored alternative and does not affect profitability. The implication of the findings for managers and future research are discussed.

The study of (Damanpour and Damanpour, 2001) cites survey evidence that many firms undertaking e-commerce projects do not appraise or evaluate them in traditional ways and discusses how businesses can deal with the many perspectives involved. Illustrates the "four faces of e-business", lists its benefits and considers seven legal/regulatory issues which require review in this context. Identifies three critical success factors for e-business, shows some international growth forecasts and compares three financing models for e-services. Briefly describes how some companies deal with security on the internet, sees e-business as "imperative" for business success and warns that, although no single strategic model fits all companies, a strategy must be developed to avoid reducing returns on investment.

\section{Relevance of the Study}

The proposed study is significant of the following reasons: Very rare Arabic studies examined the study subject. The field of the study is considered an important ICT centered sector, which contribute to the Jordanian economic growth, and also considered a leading and experienced in the e-commerce. Also, this study will provide the field of study companies and future researchers with important insights and recommendations.

\section{Research Methodology}

A descriptive - quantitative -applied research was employed to achieve the study objectives, that included collecting and converting data into numerical form so the findings can be presented. 


\subsection{Population and Sample of the study}

The population of the study consisted of mobile communication companies operating in Jordan (Zian, Umniah, Orange), A probability sample has been employed to collect the data from top and middle management team as they are working on strategic level, the sample will be consisted of 100 managers and head of departments.

Participants had been invited formally thorough the official channels to participate in the study. The purpose of the study was explained and the participant allowed to decline if he/she did not want to participate. It was assured for the participants that the data will be provided by them will be completely anonymous and no names will be collected on any of the instruments.

\subsection{Data Collection}

To achieve the goal of the study, the researcher developed a instrument to measure the variables of the study, and formed a tool of the study. Reliability is a mechanism employed to check the internal consistency of test questions against every other test item when completed by different participants. In order to estimate reliability, 30 questionnaires were sent to employees. Overall Cronbach's alpha for the sample was 0.83 which indicate an excellent level of statistical internal consistency. Sequentially to increase the content validity of the research instrument, the questionnaire was "pilot-examined" by interviewing 5 managers and experts in the mobile communication companies operating in Jordan (Zian, Umniah, Orange) who agreed to fill in the questionnaire and also to comment on the balance working. Then, their suggestion was composed and some reformations were made to improve validity of questionnaire.

The Restrictions of the Study and its Determinants

The boundaries of the study and its determinants as follows:

- The application of this study was limited to employees in mobile communication companies operating in Jordan (Zian, Umniah, Orange) in 2013.

- Determined that the results of this study on the implications of validity and reliability of the tools in the study used.

\subsection{Analytical procedures}

Five points Likert scale has been coded to enter the data into Statistical Package for Social Sciences (SPSS) software in order to achieve the study objective. The levels of the scale were given the following rating: (1) strongly disagree, (2) disagree, (0) neutral, (4) agree and (5) strongly agree. To get the general results of the study, the mean and the standard deviation of different responses to the statements were calculated using (SPSS). The responses treated according to the following scale (1-2.49) weak response, (2.50-3.49) moderate response, and (3.50- 5) high response.

\section{Hypotheses test}

In order to test hypotheses research, we used SPSS 22 software. The results of the analysis have been discussed below. 
Hypothesis Ho1: There is no statistically significant relation between E-commerce adoption (website for corporate, website for product / services, customer support via web contact details, online order processing online business, web access to order, web-based marketplaces) and business strategy at the Jordanian telecommunication companies.

Table 2. Results of Testing the Main Hypothesis

\begin{tabular}{|c|c|c|c|c|c|}
\hline $\begin{array}{c}\text { Hypothesis } \\
\text { Ho1 }\end{array}$ & F. calculated & $\mathrm{R}$ & $\mathrm{R}^{2}$ & F-Sig. & Result of H0 \\
\hline * & 19.012 & .749 & .562 & .000 & Rejected \\
\hline
\end{tabular}

As shown in table (2) multiple regressions were used to test the main hypothesis.

It was found that (calculated $\mathrm{F}=19.012$ ) is greater than tabulated $\mathrm{F}$, and the significance of "F" value is (.000). Therefore, according to the rule: "Accept $\mathrm{H} 0$ if calculated value is less than tabulated value and reject $\mathrm{H} 0$ if calculated value is greater than tabulated value". The null hypothesis ( $\mathrm{H} 0)$ is rejected and the alternate hypothesis is accepted, the value of correlation $(\mathrm{R}=0.749)$ reflects positive correlation which means that there is a statistically significant correlation between E-commerce adoption and business strategy at the Jordanian telecommunication companies. Therefore, the alternate hypothesis is accepted. Moreover, $\left(\mathrm{R}^{2}=.562\right)$ which means

over $(56 \%)$ of the variation in business strategy has been explained by E-commerce adoption. Thus the relationship established is that as the level of E-commerce adoption improve or increase, the higher chance that business strategy achieves at the Jordanian telecommunication companies.

A (T) test was used to test the sub-hypotheses of the study, and table (3) illustrates the test result for all the sub-hypotheses.

Table 3. Results of Testing the Sub-hypothesis

\begin{tabular}{|l|c|c|c|c|c|}
\hline \multicolumn{1}{|c|}{ Sub-hypothesis } & t & $\begin{array}{c}\text { Sig. (2 } \\
\text { tailed) }\end{array}$ & $\begin{array}{c}\text { Mean } \\
\text { Difference }\end{array}$ & SD & $\begin{array}{c}\text { Result of } \\
\text { Ho }\end{array}$ \\
\hline website for corporate & 36.692 & .000 & 2.6589 & .71000 & Rejected \\
\hline $\begin{array}{l}\text { website for product } \\
\text { /services }\end{array}$ & 44.974 & .000 & 2.3359 & .50891 & Rejected \\
\hline $\begin{array}{l}\text { customer support via web } \\
\text { contact details }\end{array}$ & 32.171 & .000 & 2.2917 & .69795 & Rejected \\
\hline $\begin{array}{l}\text { online order processing } \\
\text { online business }\end{array}$ & 32.256 & .000 & 3.0833 & .93659 & Rejected \\
\hline web access to order & 25.699 & .000 & 2.7188 & $\mathbf{1 . 0 3 6 5 9}$ & Rejected \\
\hline web-based marketplaces & 22.11 & .000 & $\mathbf{1 . 8 2 2 9}$ & $\mathbf{. 8 0 7 7 9}$ & $\underline{\text { Rejected }}$ \\
\hline
\end{tabular}

The decision rule has been adopted to accept the alternative hypothesis and reject the null 
hypothesis if the calculated $(\mathrm{T})$ value is greater than the indexed $(\mathrm{T})$, and accept the null hypothesis and reject the alternative hypothesis if the calculated $(\mathrm{T})$ value is less than the indexed (T) value at the level of significance (0.05), so as shown in table (2), since the t-statistic falls in the rejection region we reject the all null sub-hypotheses. Thus, e-commerce adoption levels have influence on business strategy.

\section{Conclusions}

Based on the proposed study finding the main conclusion of the study are as follows:

E-commerce adoption is a fruitful organizational instrument that impact different organizational levels including the strategic direction. The telecommunication sector in Jordan is among the potential ICT leaders that are expected to adopt high level of E-commerce locally and regionally.

Based on the literature review: E-commerce adoption was founded to impact several factors within the organizational strategy: (internal factors, market factors, competitive factors), and Jordan as a developing country is lacking the adequate infrastructure of E-commerce.

E-commerce adoption may have both negative and positive effect on business strategy, that needs to be verified by more scholars in difference contexts. Several (controllable, uncontrollable) factors impact the final decision that the consumer made within the E-commerce context.

More research is needed to highlight the importance of e-commerce adoption in organizational strategy.

\section{References}

Al-Nawayseh, M. K. (2012). Electronic Commerce Logistics in Developing Countries: The Case of Online Grocery Shopping in Jordan, Ph.D Dissertation, Brunel University, London, UK.

Ambler, Scott W. (2003). IBM Developer Library, "Project planning tips": available (online)http://www.stsc.hill.af.mil/resources/tech_docs/gsam4/chap3.pdf, retrieved in 12-8-2013.

Arab Advisors Group report. (2011). e-commerce in Jordan, available (online): http://www.arabadvisors.com/Pressers/presser-240412.htm, retrieved in 1-10-2013.

Barkley, David L., Deborah M. Markley, \& R. David Lamie. (2007). E-Commerce as a Business Strategy: Lessons Learned From Case Studies of Rural and Small Town Businesses. Southern Rural Development Center's National Rural e-Commerce Extension Initiative. Washington D.C.: U.S. Department of Agriculture, No. 2005-45064-03212. Accessed online August 17, 2013 at http://www.energizingentrepreneurs.org/site/images/research/cp/cs/cs7.pdf.

Banaghan, Margaret, \& Bryant, Gayle. (1998). Electronic Commerce Streamlines The Supply Chain. Business Review Weekly, September 7, 56-67. 
Chaffey, Dave's. (2011). E-Business \& E-Commerce Management. $4^{\text {th }}$ edition Prentice Hall.

Chen, S. (2004). Adoption of electronic commerce by SMEs in Taiwan. Electroniccommerce studies, 2(1), 19-34.

Cheung, C.M.K., Zhu, L., Kwong, T., Chan, G.W.W., \& Limayem, M. (2003).Online consumer behavioural review and agenda for future research. Proceedings of the 16th Bled E-commerce Conference, Bled, 9-11 June.

Constantinides, E. (2004). Influencing the online consumer's behavior: The web experience. Journal of Internet Research: Electronic Networking Applications and Policy,14(2), 111-126. http://dx.doi.org/10.1108/10662240410530835

Costello, G.I., \& Tuchen, J.H. (1998). A Comparative Study of Business to Consumer Electronic Commerce within the Australian Insurance Sector. Journal of Information Technology, 13(3), 153-16. http://dx.doi.org/10.1080/026839698344800

Faramarz Damanpour, \& Jamshid Ali Damanpour. (2001). E-business e-commerce evolution: perspective and strategy. Emerald, 27.

Fruhling, A.L., \& L.A. Digman. (2000). The Impact of Electronic Commerce on Business Level Strategies. Journal of Electronic Commerce Research, 1(1), 13-22.

Gome, Amanda. (2000). Fair Trade or Foul? Business Review Weekly, July 21.

Govindaraju, R., \& Chandra, D. (2012). Analysis of Level and Barriers of E CommerceAdoption by Indonesian Small, Medium, andMicro Enterprises (SMMEs). Internetworking Indonesia Journal, 4(1), 9-14.

Hannen, Michelle. (2000). Another Life In The E-World. Business Review Weekly, July 21.

Ipsos. (2012). Interconnected World: Shopping and Personal Finance, available (online): http://www.ipsos-na.com/news-polls/pressrelease.aspx?id=5573, retrieved in 1-3-2013.

Kraemer, K., Gibbs, J., \& Derick, J. (2002). Impacts ofglobalization on e-commerce adoption and firm performance: A cross countryinvestigation. Center For Research On Information Technology And Organization ,University of California, Irvine.

King R. C., Sen R., \& Xia M. (2004). Impact of Web-based e-Commerce on Channel Strategy in Retailing. International Journal of Electronic Commerce, 8(3), 103-130.

Kurnia, S. (2007). Identifying e-Commerce Adoption Driving Forces and Barriers: The Case of the Indonesian Grocery Industry, Brunel University, London, UK.

Levy, Marc. (2000). B2B The Way 2B. Business Review Weekly, September 1.

Nickels, D. W., Kwun, O., \& Omar, A. (2008). The effect of organizational culture on ecommerce adoption.

Necmi Karagozoglu, \& Martin Lindell. (2004). Electronic commerce strategy, operations, and performance in small and medium-sized enterprises. Journal of Small Business and 
Enterprise Development, 11(3), 290 - 301. http://dx.doi.org/10.1108/14626000410551555

Pires, G. D., \& Aisbett, J. (2003). The relationship between technology adoption and strategy in business-tobusiness markets - The case of e-commerce. Industrial Marketing Management, 32, 291-30. http://dx.doi.org/10.1016/S0019-8501(02)00237-7

Rao, S. S., Metts, G., \& Monge, C.A.(2003). Electronic Commerce Development in Small and Medium Sized Enterprises: A Stage Model and Its Implications. Business Process Management Journal, 9(1), 11-32. http://dx.doi.org/10.1108/14637150310461378

Sculopa, A. (2003). The Adoption of Internet Commerce by SMEs in the South of Italy: An Environmental, Technological and Organizational Perspective. Journal of Global Information Technology Management, 6(1), 52-71.

Senarathna, P., \& Wickramasuriya, H. (2011). Organizational Factor Affecting E-Commerce Adoption in Smalland Medium-sized Enterprises. Tropical Agriculture Research, 22(2), 204-210.

Shen, L., Hawley, J., \& Dickerson, K. (2004). Ecommerce Adoption for Supply Chain Management in U.S. Apparel Manufacturers. Journal of Textile and Apparel, Technology and Management, 4(1), 1-11.

Shen, L., Hawley, J., \& Dickerson, K. (2004). Ecommerce Adoption for Supply Chain Management in U.S. Apparel Manufacturers. Journal of Textile and Apparel, Technology and Management, 4(1), 1-11.

Tan, M.S., \& Ibrahim, I.S. (2010). Supply Chain Management and E-Commerce Technology Adoption among Logistics Service Providers in Malaysia. World Academy of Science, Engineering and Technology, 451-456.

Warden, S., \& Motjolopane, I. M. (2007). E-commerce adoption factors: supporting cases from South Africa. In Information Resource management Association conference, Vancouver, Canada. Available

(Online):

http://www.stuartwarden.com/Motjolopane_Warden_\%20Electronic\%20commerce\%20adopt ion\%20approaches\%20by\%20SMMEs_IRMA2007.pdf. Retrieved in: 3-8-2013.

Waboi, A. (2012). Effectiveness Of International E-Commerce Strategy Among Selected Registered Motor Vehicle Dealers In Nairobi, Kenya. Available (Online): http://business.uonbi.ac.ke/node/1738, retrieved in 12/08/2013.

Yang, M. (2012). Supply Chain Management under E-Commerce Environment. International Journal of Innovation, Management and Technology, 3(3), 2010-2012.

Yao, JT (2004). E-commerce adoption of ins urance companies in New Zealand. Journal of Electronic Commerce Research, 5(1), 54-61. 